\title{
Charakterystyka motywów zachowań finansowych młodych ludzi
}

\section{Wstęp}

Zachowania finansowe stanowią ważny aspekt zachowań konsumentów, który obecny jest w nabywaniu, pozyskiwaniu oraz utrzymywaniu dóbr i usług. Pojawiające się ograniczenia budżetowe stawiają konsumentów przed koniecznością analizowania spraw finansowych oraz podejmowania decyzji, które odnoszą się do gospodarowania pieniędzmi.

Celem artykułu jest charakterystyka głównych motywów zachowań finansowych i identyfikacja zachowań konsumentów powstających pod wpływem tych motywów. W artykule przeanalizowano teorie i koncepcje dotyczące zachowań finansowych i zarządzania pieniędzmi oraz zaprezentowano wyniki badania pierwotnego przeprowadzonego w wybranej grupie studentów Uniwersytetu Łódzkiego. Badanie pozwoliło na identyfikacje motywów zachowań finansowych młodych ludzi oraz wskazało na wykorzystywane przez nich produkty finansowe.

\section{Zachowania finansowe $i$ ich motywy}

Zachowania finansowe związane są z różnymi decyzjami odnoszącymi się do gospodarowania pieniędzmi. Będą one obejmować zatem takie procesy i zachowania, jak pozyskiwanie i zarządzanie pieniędzmi, oszczędzanie, inwestowanie, zadłużanie się, ubezpieczenia na życie, ubezpieczenie majątku czy płacenie podatków ${ }^{1}$. W takim ujęciu chodzi przede wszystkim o sposoby gromadzenia, przechowywania i wydatkowania pieniędzy. Takie zachowania rozpatrywane pod kątem czasu mają na celu zaspokajanie obecnych i przyszłych potrzeb. Realizacja

1 J. Woś, J. Rachocka, M. Kasperek-Hoppe, Zachowania konsumentów. Teoria i praktyka, Wyd. Uniwersytetu Ekonomicznego, Poznań 2011. 
przyszłej konsumpcji jest możliwa poprzez alokację środków finansowych. W obecnych czasach skłania konsumenta do większego lub mniejszego udziału w rynku finansowym. Wiąże się to także z motywami oraz umiejętnościami korzystania z szerokiej oferty usług finansowych. Rynek ten daje ogromne możliwości wyboru metod zagospodarowania nadwyżek finansowych, jak również dokonywania zakupów z wkorzystaniem pożyczonych środków. Należy jednak pamiętać, że podejmowanie takich decyzji przez konsumentów jest zdecydowanie trudniejsze niż w przypadku innych dóbr i usług, a to ze względu na złożoność produktów finansowych, bardziej skomplikowany proces decyzyjny, wyższy poziom postrzeganego ryzyka, jak również konieczność posiadania wiedzy dotyczącej finansów. Oprócz wymienionych czynników występują także różne motywy podejmowania przez ludzi poszczególnych zachowań finansowych, nie tylko związane z ofertą rynku finansowego.

Podczas analizy zachowań finansowych istotna jest identyfikacja czynników psychologicznych, które wyznaczają ogólne kierunki i cele życiowe, kształtują postawy osób wobec pieniędzy oraz bogactwa. Powstają one już we wczesnym dzieciństwie i mogą pozostać na całe życie. Postawy ludzi wobec pieniądza uwzględniają trzy zasadnicze elementy. Pierwszy z nich to element emocjonalny. Pozwala on na interpretację pieniądza jako czegoś, co jest odbierane przez człowieka jako dobre lub złe. Kolejno, element poznawczy pozwala ludziom dostrzegać powiązania pieniądza z posiadaniem wolności, cieszeniem się szacunkiem czy odnoszeniem sukcesów. W przypadku trzeciego elementu - behawioralnego, ludzie zwracają uwagę na potrzebę planowania swoich wydatków ${ }^{2}$.

Konsumenci wyznaczają zróżnicowane cele finansowe, a ich następstwem jest planowanie zachowań finansowych, poprzedzone identyfikacją indywidualnych potrzeb. Planowanie takie obejmuje trzy poziomy:

- poziom strategiczny - czyli decyzji długofalowych, mogą to być aspekty finansowe i organizacyjne wyboru wykształcenia, wykonywanego zawodu, partnera, posiadania dzieci;

- poziom wykonawczy - dotyczący rejestrowania wpływów i wydatków (sporządzania kalkulacji i tworzenia budżetu);

- poziom operacyjny - czyli robienie zakupów, płacenie rachunków i podatków ${ }^{3}$.

Efektywne zarządzanie finansami zmusza konsumenta do precyzowania celów finansowych i ich planowania zarówno długo-, jak i krótkookresowego.

\footnotetext{
${ }^{2}$ A. Kozak, Jaki jest twój pieniądz?, „Marketing i Rynek” 2004, nr 1.

${ }^{3}$ G. Antonides, W.V. Van Raij, Zachowania konsumentów. Podręcznik akademicki, Wyd. Nauk. PWN, Warszawa 2003.
} 
Cele finansowe są efektami, jakie konsument chce osiągnąć. Cele długookresowe uwzględniają potrzeby konsumenta w dłuższej perspektywie. Jednak czasami są trudne do sprecyzowania. Nie będą miały charakteru statycznego i będą ulegać zmianom w czasie. Natomiast cele krótkookresowe określane są na bieżąco i pomagają w zarządzaniu bieżącym budżetem ${ }^{4}$. Na rys. 1 przedstawiono powiązania planowania finansowego, podejmowania przez konsumentów określonych działań finansowych oraz efektów finansowych, wszystkie elementy składają się na zarządzanie finansami prywatnymi.

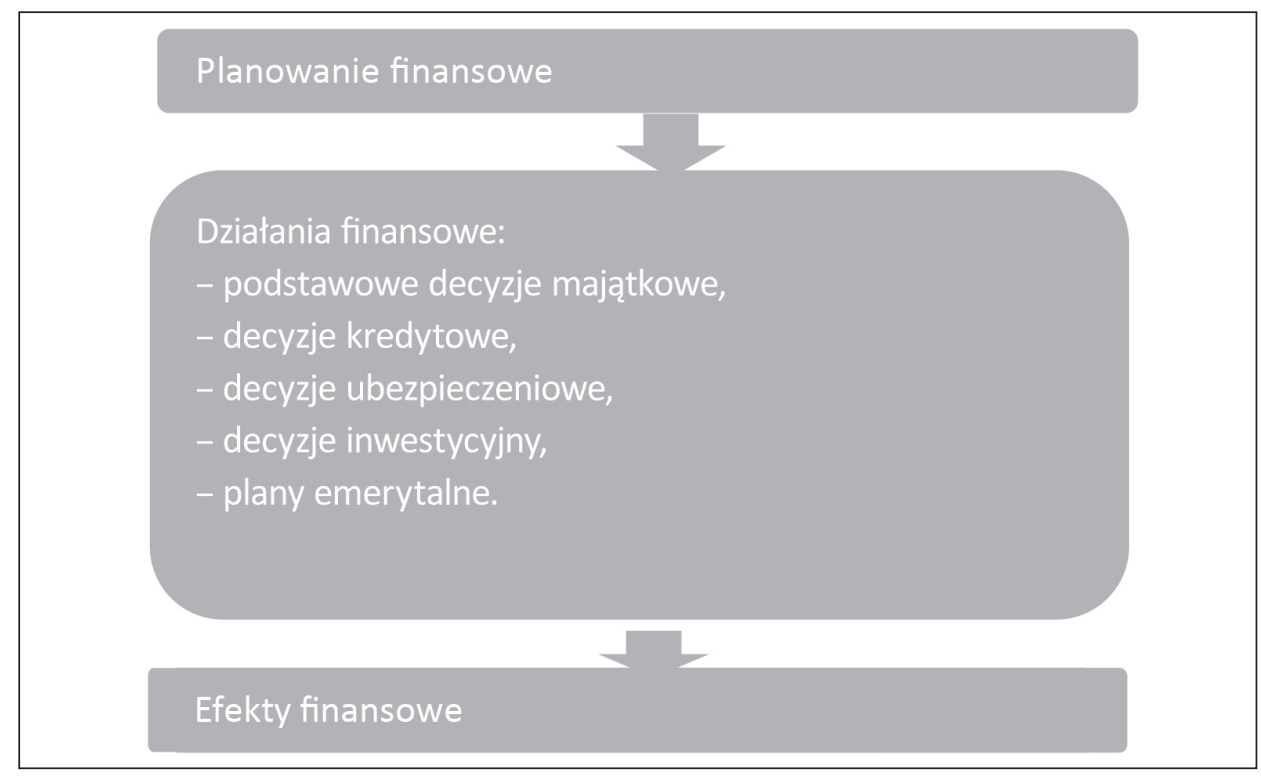

Rysunek 1. Zarządzanie finansami prywatnymi

Źródło: L.J. Gitman, M.D. Joehnk, Personal Financial Planning, The Dryden Press, Chicago 1993, s. 29.

Zachowania finansowe uzależnione są od cyklu życia danej osoby. Poszczególne etapy życia powodują zmianę sytuacji zarówno ekonomicznej, jak i społecznej. Wymuszają na konsumencie modyfikację dotychczasowych zachowań finansowych i mają wpływ na korzystanie z różnych usług kapitałowych. Na tym polu powstała ekonomiczna teoria finansowego cyklu życia. Jej głównym założeniem jest przekonanie, że sytuacja ekonomiczna człowieka jest zróżnicowana w czasie i dlatego niezbędna jest umiejętność przewidywania efektywnego korzystania z zasobów pieniężnych w taki sposób, aby zabezpieczyć obecne

${ }^{4}$ L.J. Gitman, M.D. Joehnk, Personal Financial Planning, The Dryden Press, Chicago 1993. 
i przyszłe dochody. Ludzie posiadają umiejętność przewidywania i zarządzania swoim majątkiem w czasie i planują swoją konsumpcję w perspektywie życia jako całości. W teorii tej przyjęto także, że ludzie będą ograniczać swoją konsumpcję w danym okresie, aby w przyszłości było ich stać na podobny poziom konsumpcji ${ }^{5}$.

Podważenie założenia o racjonalności jednostki pozwoliło na stworzenie behawioralnej hipotezy cyklu życia, która oparta jest na koncepcji samokontroli ${ }^{6}$. Wydawać by się mogło, że w przypadku posiadania wolnej kwoty pieniędzy zachowaniem właściwym będzie konsumpcja. W sytuacji oszczędzania takie odruchy są hamowane. W literaturze spotykamy dwa typy zachowań: wykonawcy i planisty. Pierwszy typ charakterystyczny jest dla osób, które wydają pieniądze od razu, są krótkowzroczne, egoistyczne i zorientowane hedonistycznie. Drugi przedstawia stratega maksymalizującego swoją użyteczność w długim czasie, wybierającego ścieżkę długofalową i odraczającego zaspokajanie potrzeb. Ma na to wpływ preferencja czasowa, a także ustalanie przez jednostki pewnych priorytetów. Należy tutaj odpowiedzieć sobie na pytanie, w jakim stopniu człowiek woli otrzymywać mniejsze pieniądze w danej chwili niż uzyskiwać kwotę większą w odstępie czasu. Opcja, na którą decyduje się jednostka, będzie także uzależniona od wysokości różnicy w obu przypadkach. Badania psychologów pokazują, że każdy ma inną tolerancję na tę różnicę.

Podejmowane przez jednostki zachowania finansowe lub też zaniechanie takich zachowań może wynikać z różnych motywów. One określają konkretne zachowanie konsumenta i są bezpośrednio motorem oraz przyczyną działań. Istnieje szereg klasyfikacji motywów, które wywołują określone zachowania finansowe. W teoriach ekonomicznych wyróżnia się cztery główne motywy dotyczące oszczędzania:

- motyw transakcyjny - wiąże się z potrzebą utrzymywania pieniędzy w postaci płynnej w celach rozliczeniowych i regulacji zobowiązań;

- motyw przezornościowy - polega na utrzymaniu zasobów pieniężnych na pokrycie nieprzewidzianych wydatków;

- motyw celowości - pojawia się w sytuacji, gdy środki finansowe gromadzone są w określonym celu, np. na większe wydatki lub zakupy;

- motyw portfelowy - swoje źródło ma w różnym podejściu ludzi do podejmowania ryzyka, czyli np. oszczędzania lub podejmowania inwestycji czy lokowania pieniędzy w produkty finansowe o różnym stopniu ryzyka.

Postrzeganie czasu przez jednostkę wpływa na ocenę obecnych i przyszłych potrzeb finansowych. To z kolei implikuje motywy opisujące cele, na jakie lu-

\footnotetext{
5 J. Harasim, Oszczędzanie i inwestowanie indywidualne w Polsce, PTE, Katowice 2007.

${ }^{6}$ T. Tyszka, Psychologia ekonomiczna, GWP, Gdańsk 2004.
} 
dzie odkładają pieniądze. Badania dostarczają wielu wyników i klasyfikacji, co do określania motywów podejmowania przez ludzi oszczędności. W psychologicznym schemacie badań nad oszczędzaniem wskazuje się na motywy, które wynikają z dostrzeżenia przez jednostkę przyszłych potrzeb. Potrzeby te stają się bodźcami do ograniczenia bieżącej konsumpcjī. Należą do nich:

- zarządzanie gotówką, czyli konieczność posiadania pieniędzy na planowane wydatki;

- bezpieczeństwo, potrzeba posiadania pieniędzy wynikająca z krótkoterminowego kapitału buforowego lub z zabezpieczeń na emeryturę;

- pozostawienie spadku - wynika z chęci pozostawienia majątku dla przyszłych pokoleń;

- unikniecie ubóstwa - chęć posiadania środków zapewniająca zachowanie określonego poziomu życia.

Inne klasyfikacje odnoszące się do subiektywnych cech człowieka wskazują na motywy: ostrożności, przezorności, wyrachowania, poprawy bytu, niezależności, przedsiębiorczości, dumy czy skąpstwa.

Biorąc pod uwagę wieloznaczność badań można tutaj zauważyć, że pośród wielu klasyfikacji motywów wyłaniają się czynniki je wywołujące, takie jak dobrowolność oszczędzania, przeznaczenie, cel oszczędności, forma oszczędności czy czas i jego perspektywa ${ }^{8}$.

Różnorodność powodów oszczędzania widoczna jest także w zachowaniach finansowych gospodarstw domowych w Polsce. Jak wynika z raportu Diagnoza społeczna przeprowadzonego w roku 2009 można dokonać podziału gospodarstw domowych ze względu na cele gromadzenia środków oszczędnościowych ${ }^{9}$. Przedstawione w raporcie wyniki wskazują, że ponad jedna piąta wszystkich badanych zbiera pieniądze na bieżące potrzeby konsumenckie. Drugą pod względem liczebności grupą są odkładający na zakup dóbr trwałych czy remont, na trzecim miejscu znalazły się gospodarstwa oszczędzające z przeznaczeniem na tworzenie rezerw na sytuacje losowe.

Stopa oszczędzania spada w Polsce od 15 lat i stanowiła 5\% w roku $2012^{10}$. Z sondażu przeprowadzonego przez TNB OBOP wynika, że aż 74\% Polaków nie posiada oszczędności. W tej grupie badanych najliczniejszą grupą są nastolatki,

7 Ibidem.

${ }^{8} \mathrm{~J}$. Harasim, Oszczędzanie i inwestowanie nadwyżek finansowych przez ludność, [w:] Oszczędzanie i inwestowanie w teorii i praktyce, red. J. Harasim, PTE, Katowice 2010.

9 J. Czapiński, T. Panek, Diagnoza społeczna 2009. Warunki i jakość życia Polaków, raport, Warszawa 2009.

${ }^{10}$ Raport ekspertów banku BGŻ Optima, http://www.parkiet.com/artykul/1268669.html, [dostęp: 12.07.2012]. 
bezrobotni, rolnicy, robotnicy, emeryci i renciści oraz uczniowie i studenci. Z raportu wynika, że są to zazwyczaj osoby młode lub po 60. roku życia. Potwierdzeniem tego mogą być wyniki kolejnego raportu TNS Pentor z października $2011 \mathrm{roku}^{11}$. W raporcie dokonano segmentacji Polaków ze względu na ich podejście do oszczędzania. Na grupę „beztroskich” najwięcej przypada młodych ludzi mieszkających z rodzicami. Przeznaczają oni większość swoich środków finansowych na konsumpcję bieżącą. Mają świadomość, że zdążą zadbać o swoje środki w przyszłości, nie planują wydatków i sami określają się mianem rozrzutnych.

\section{Opis badania}

Zarządzanie finansami to efektywne wykorzystanie posiadanych zasobów finansowych. Znajomość produktów rynku finansowego i zasad jego funkcjonowania ułatwia zarządzanie oszczędnościami i ich inwestowanie. Celem przeprowadzonego badania była próba zidentyfikowania motywów zachowań finansowych nabywców względem usług, z jakich korzystają ${ }^{12}$. Badanie wskazywało na motywy oszczędzania i inwestowania oraz określało czynniki je kształtujące. Zostało przeprowadzone w maju 2011 roku wśród studentów Uniwersytetu Łódzkiego. W badaniu przyjęto założenie, że młodzi ludzie to osoby w wieku 19-25 lat. Stwierdzono, że jest to grupa wiekowa osób, u których proces socjalizacji pierwotnej już się zakończył i postawy wobec pieniędzy i zachowań finansowych są w dużej części uformowane. Należy także stwierdzić, że większość badanych to osoby urodzone na przełomie lat osiemdziesiątych i dziewięćdziesiątych. Oznacza to, że ich wczesny rozwój konsumencki był kształtowany w przyjaznych warunkach gospodarczych kraju. Można zatem również przyjąć, że miało to pozytywny wpływ na kształtowanie się u nich postaw wobec finansów i oszczędzania. Badanie zostało przeprowadzone $\mathrm{z}$ wykorzystaniem ankiety audytoryjnej wśród studentów trzeciego roku studiów licencjackich Wydziału Zarządzania Uniwersytetu Łódzkiego.

W badaniu posłużono się wystandaryzowanym kwestionariuszem ankiety z użyciem skali Likerta. Gruba badanych liczyła 113 osób. Analizie poddano 113 kompletnych ankiet. Średni wiek badanego to 22,17 roku (odchylenie standar-

${ }^{11}$ Postawy Polaków wobec oszczędzania, 2011, Raport z Fundacji Kronenberga przy City Handlowy TNS Pentor, październik 2011, http://www.citibank.pl/poland/kronenberg/polish/files/ fk_oszcz_2011.pdf [dostęp: 15.02.2013].

12 Badanie miało szerszy zakres przedmiotowy, jednak w artykule zostaną przedstawione wyniki w odniesieniu do motywów konsumentów. 
dowe $\left.\mathrm{s}^{2}=0,30\right)$. Grupa składała się z 98 kobiet i 15 mężczyzn. Rozkład respondentów ze względu na płeć nie był brany pod uwagę. Uzyskane wyniki badania miały charakter deklaratywny, pomimo zastosowania w ankiecie pytań projekcji zachowań.

\section{Motywy zachowań finansowych młodych ludzi - wyniki badania}

W badaniu dokonano analizy, z jakich produktów korzystają konsumenci oraz jakie deklarują powody korzystania $\mathrm{z}$ tych produktów. Respondenci deklarowali korzystanie z różnych usług. Aż $96 \%$ badanych deklarowało posiadanie konta bankowego, ponadto $62,8 \% \mathrm{z}$ nich również dysponowało kontem oszczędnościowym. Na trzecim miejscu znalazło się ubezpieczenia na życie - 59,3\%. Natomiast zdecydowanie mniej osób korzysta z produktów inwestycyjnych $(8 \%)$ czy kredytowych $(15,9 \%)$. Potwierdzałoby to inne wyniki badań dowodzących, że osoby młode korzystają najczęściej z produktów pozwalających zarządzać ich finansami prywatnymi, w mniejszym stopniu zaś pozyskują obce środki pieniężne na sfinansowanie swoich planów czy inwestują nadwyżki.

W dalszej kolejności badani deklarowali powody oraz motywy wyboru produktów finansowych. $\mathrm{Z}$ badania wynika, że powodów założenia konta jest wiele. Respondenci postrzegają je jako nieodzowne narzędzie finansowe. Wskazywali, że posiadanie rachunku bieżącego jest w obecnych czasach koniecznością, choć motywy jego założenia bywają różne. Założenie konta z własnej woli deklarowało prawie $49 \%$ badanych. $Z$ przyczyn zawodowych otworzyło rachunek bankowy $29,2 \%$ z nich. W tym przypadku takie zachowanie finansowe stanowiło przymus wynikający z nakazu pracodawcy. Badani wskazywali także na korzyści oraz wygodę. W pierwszym przypadku (23,9\%) posiadanie konta wynika z korzyści, w drugim $(49,6 \%)$ z dostępu do środków w krótkim czasie oraz bezpieczeństwa.

W badaniu wystąpiły różne formy lokowania oszczędności. Najczęstszą formą oszczędzania jest lokata bankowa, korzysta z niej 42,5\% badanych. Inwestowanie oszczędności na lokatach terminowych lub koncie oszczędnościowym okazało się najczęstsza formą lokowania nadwyżek finansowych. Znacznie mniejsza liczba respondentów $(12,5 \%)$ inwestuje swoje oszczędności w nieruchomości. Respondenci inwestowali również $\mathrm{w}$ fundusze inwestycyjne $(6,2 \%)$ oraz obligacje skarbowe $(1,8 \%)$. Brak wiedzy o dostępnym produkcie na rynku, niechęć do ryzyka oraz nieumiejętność inwestowania staje się przyczyną nieefektywnego lokowania oszczędności, jak również trzymania oszczędności w domu (3,5\% - por. rys. 2). 


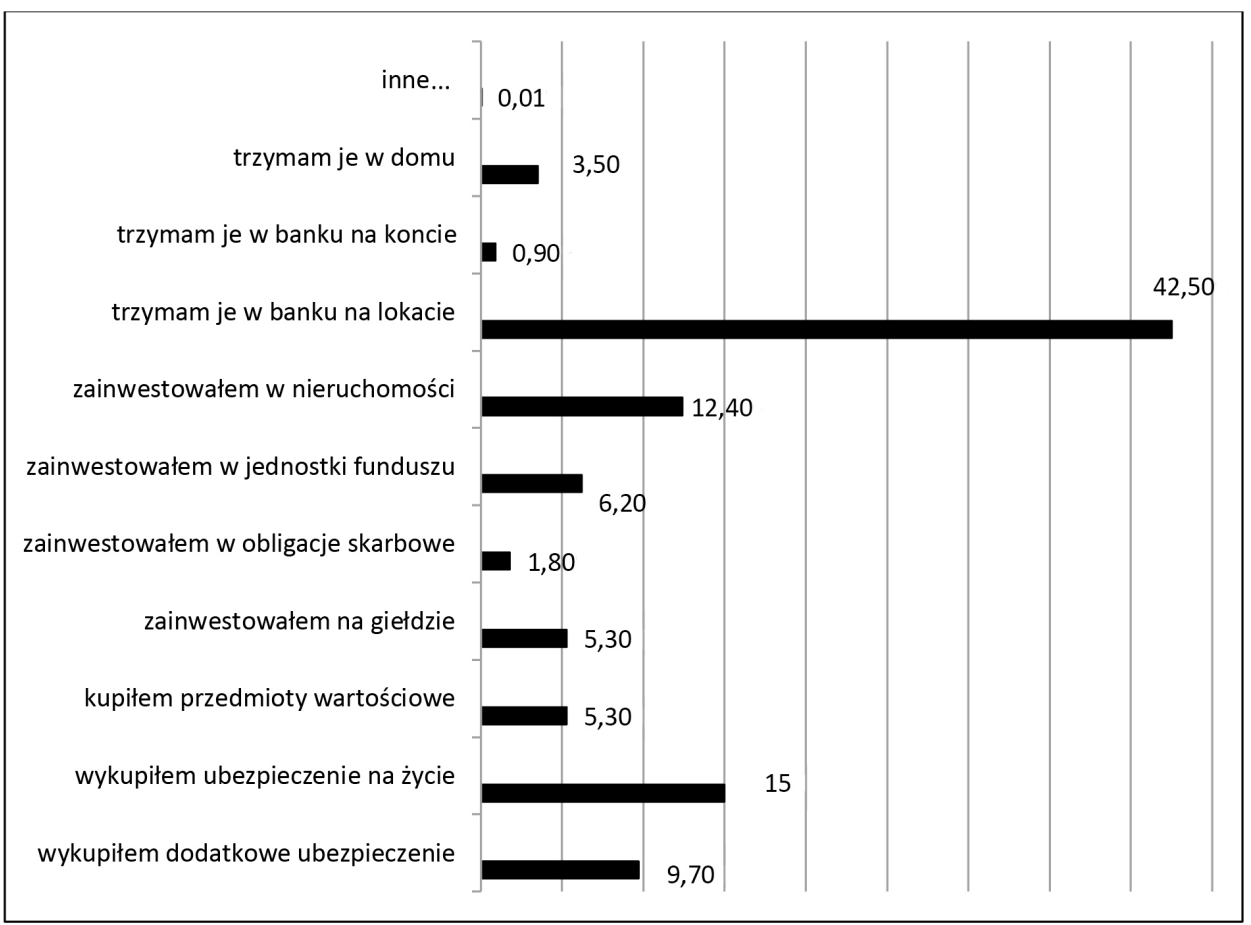

Rysunek 2. Utrzymywanie oszczędności (w \%)

Źródło: opracowanie własne na podstawie badania.

$\mathrm{Z}$ badania wynika, że respondenci dostrzegają w oszczędzaniu działanie dające poczucie własnej wartości, przynoszące satysfakcję, niezależność, uznanie, a nawet wrażenie dominacji nad innymi. Najczęściej wymienianymi motywami skłaniającymi respondentów do oszczędzania okazały się oszczędzanie na „czarną godzinę", oszczędzanie dla poprawienia sytuacji finansowej oraz oszczędzanie dla osiągnięcia własnej niezależności. Zgodnie z tymi motywami respondenci gromadzą pewne zapasy środków finansowych, aby w przypadku nieoczekiwanego splotu przyszłych wydarzeń posiadać rezerwę zabezpieczającą przed przykrymi konsekwencjami. Przedsiębiorczość polega na polepszaniu sytuacji materialnej poprzez obrót pieniędzmi, lokowanie oszczędności czy też obrót nieruchomościami. Zaledwie niecałe $13 \%$ respondentów do oszczędzania motywują te przesłanki (rys. 3). Inwestowanie jest jednym z podstawowych obszarów planowania finansowego. Towarzyszy nam przez całe życie. $Z$ jednej strony inwestycje mogą przynosić duże dochody, z drugiej zaś musimy się liczyć z niską płynnością i brakiem efektów osiągnięcia zysków. 


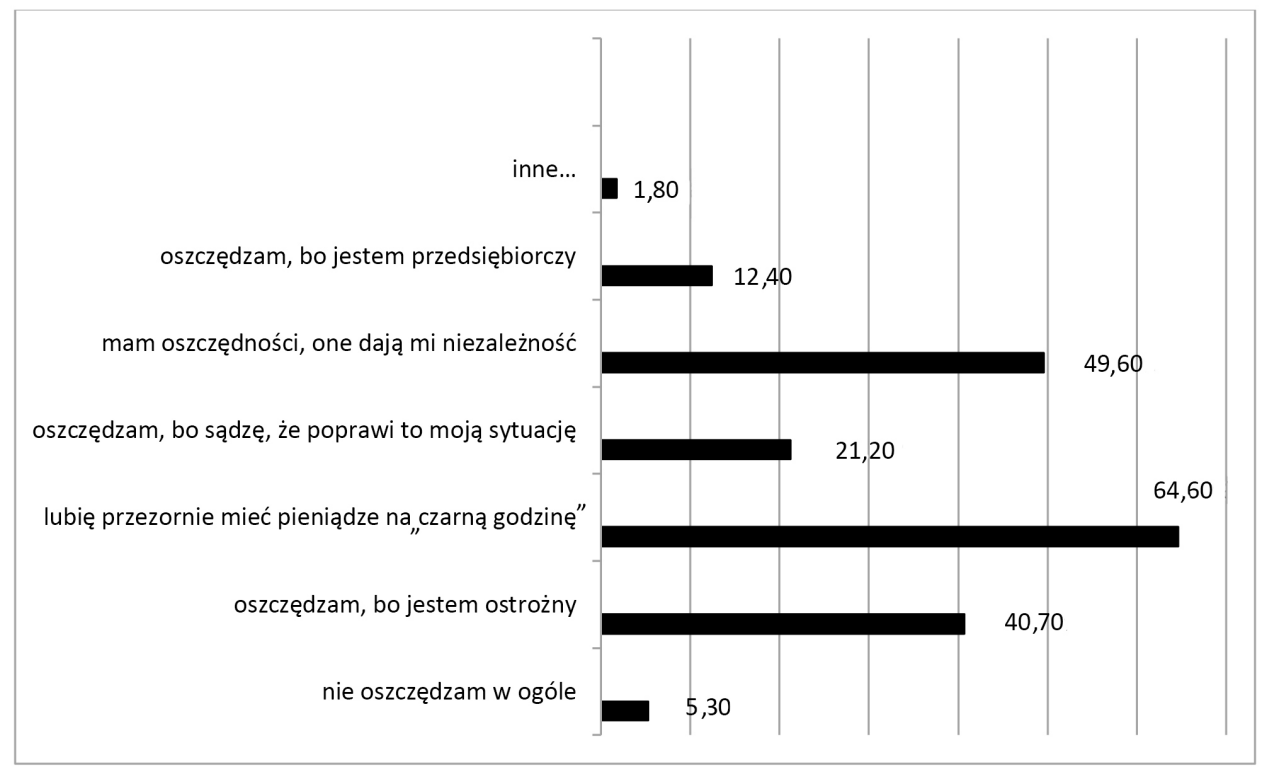

Rysunek 3. Motywy oszczędzania (w \%)

Źródło: opracowanie własne na podstawie badania.

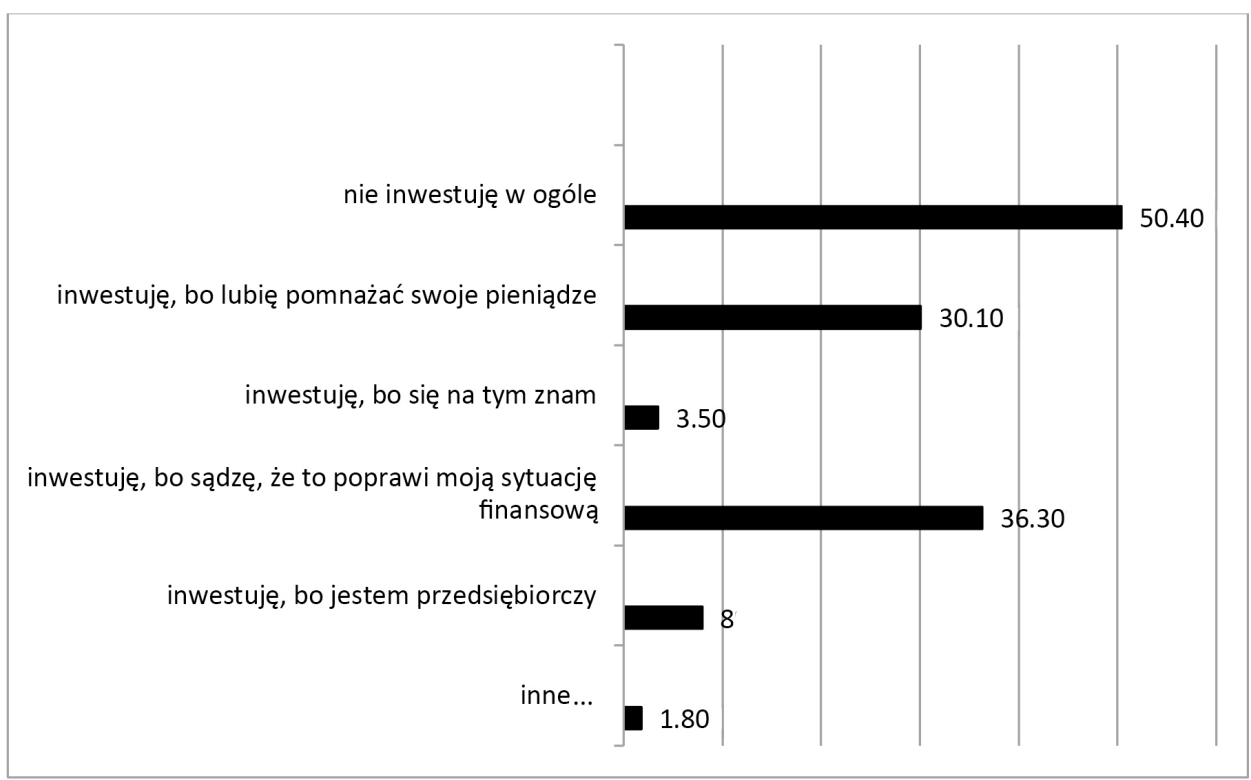

Rysunek 4. Motywy inwestowania (w \%)

Źródło: opracowanie własne na podstawie badania. 
Przeprowadzone badanie ukazuje, że ponad połowa badanych nie inwestuje posiadanych zasobów finansowych w ogóle. Świadczyć to może o braku wiedzy, jak również o obawie przed ryzykiem, jakie niesie inwestowanie. Pomnażanie pieniędzy to motyw, jaki deklaruje 30,1\% badanych decydujących się na inwestowanie. Kolejno 36,3\% respondentów wskazało na poprawę sytuacji materialnej jako powód inwestowania posiadanych oszczędności. Osoby uważające się za przedsiębiorcze (8\%) kierowały się tym motywem przy swoich inwestycjach.

Ponadto badani deklarowali, z jakich zobowiązań korzystają. Ponad $45 \%$ respondentów przyznała, że nie ma żadnych zobowiązań. Najwięcej, bo 27,4\% badanych podało kartę kredytową, z której korzysta. W 18,6\% respondenci wykorzystują linię debetową na koncie osobistym, a ponad 13\% korzysta z bankowych pożyczek lub kredytów. Powody posiadania zobowiązań wśród respondentów były bardzo zróżnicowane. Jednym z motywów była chęć nieangażowania swoich środków finansowych. Wśród badanych 15\% zmusiła do zaciągnięcia zobowiązań sytuacja materialna. Spłata poprzednich zobowiązań również powodowała zaciąganie kredytów i pożyczek (3,5\%). Ponadto niecałe 3\% badanych korzystało z obcych źródeł finansowania w celu otwarcia własnej działalności gospodarczej.

\section{Zakończenie}

Analiza współczesnego rynku finansowego wymaga specyficznego podejścia badawczego. Popyt na produkty finansowe wynika z relacji bieżących i przyszłych potrzeb, które wraz z dochodami nabywców i ich majątkiem kształtują cele, na które odkładane są środki finansowe. Konkretne cele wynikają z motywów i mają wpływ na skłonność konsumenta do podejmowania określonych zachowań finansowych. Część motywów ma bezpośredni związek z produktami finansowymi, inne mają wpływ na indywidualne cele osiągane za pomocą środków materialnych jednostki. Identyfikacja poszczególnych motywów wymaga dostrzeżenia wspólnych płaszczyzn z rynkiem usług finansowych. Należy się bliżej przyjrzeć, w jakim stopniu motywy zachowań finansowych skłaniają konsumentów do aktywności nabywczej i korzystania z produktów finansowych.

$\mathrm{Z}$ badania wynika, że konsumenci preferują tradycyjne, sprawdzone i jednocześnie bezpieczne rozwiązania, tj. konta bankowe. Oszczędzanie to dla badanych bezpieczeństwo i przezorność. Najbardziej popularną formą są lokaty terminowe. Tutaj także badani polegają na najmniej ryzykownych instrumentach finansowych. Można to thumaczyć brakiem doświadczenia i wiedzy oraz obawą przed utratą środków z bardziej ryzykownych produktów finansowych. 
Przeprowadzone badanie ukazuje także niski poziom korzystania z produktów inwestycyjnych. Respondenci widzą potrzebę posiadania nadwyżek finansowych, jednakże wolne środki najczęściej przechowywane są w domu. Ponadto, biorąc pod uwagę konsekwencje dla nabywców wynikające z przebiegu transformacji systemu emerytalnego, niski poziom ubezpieczenia jest niepokojący. Urzeczywistnienie określonych celów może być realizowane poprzez uzyskanie obcych środków finansowych. Badanie pokazuje, że konsumenci sceptycznie podchodzą do zaciągania zobowiązań. Najczęstszą formą są produkty, które pozwalają na kredytowanie bieżącej konsumpcji. Także sytuacja materialna skłania konsumentów do pozyskania środków na zakup nieruchomości lub pokrycie poprzednich zobowiązań.

\section{Bibliografia}

Antonides G., Van Raij, W.V., Zachowania konsumentów. Podręcznik akademicki, Wyd. Naukowe PWN, Warszawa 2003

Czapiński J., Panek T. (red.), Diagnoza społeczna 2009. Warunki i jakość życia Polaków, raport, Warszawa 2009

Gitman L.J., Joehnk M.D., Personal Financial Planning, The Dryden Press, Chicago 1993

Harasim J., Oszczędzanie i inwestowanie indywidualne w Polsce, PTE, Katowice 2007

Harasim J., Oszczędzanie i inwestowanie nadwyżek finansowych przez ludność, [w:] Oszczędzanie i inwestowanie w teorii i praktyce, red. J. Harasim, PTE, Katowice 2010

Kozak A., Jaki jest twój pieniądz?, „Marketing i Rynek” 2004, nr 1

Lindqvist A., The Saving Behavior of Houshold, [w:] Psychologia ekonomiczna, red. T. Tyszka, GWP, Gdańsk 2004 .

Postawy Polaków wobec oszczędzania, 2011, Raport z Fundacji Kronenberga

przy City Handlowy TNS Pentor, październik 2011, http://www.citibank.pl/ poland/kronenberg/polish/files/fk_oszcz_2011.pdf

Raport ekspertów banku BGŻ Optima, http://www.parkiet.com/artykul/1268669. html

Tyszka T., Psychologia ekonomiczna, GWP, Gdańsk 2004

Warneryd K., Oszczędzanie, [w:] Psychologia ekonomiczna, red. T. Tyszka, GWP, Gdańsk 2004

Woś J., Rachocka J., Kasperek-Hoppe M., Zachowania konsumentów. Teoria i praktyka, Wyd. Uniwersytetu Ekonomicznego, Poznań 2011 